\title{
Beginning, How Possible!
}

\author{
Ashok Kumar Dutta \\ Department of Logic \& Philosophy, Chaitanya Prasad Junior Mahavidyalaya, Kendua, \\ Research Scholar in Philosophy, North Orissa University, Odisha, India
}

\begin{abstract}
Modern scientists are always looking to find the genetic systems of the world and universe. One of the aims of the Scientists and Philosophers is to find, to discover how the world created. What are the causes behind the creation of the world? Space researchers have discovered water in the surface of moon in the form of solid. So, why men are searching the source from which all the material substances came to existence? Why can't man go beyond the area of solar family as they like, where to find the actual source of universe? What are the real problems behind it? These are the thrust area to be analyzed, rediscovered unto philosophical thinking of some notable and unknowable Thinkers of India and abroad.
\end{abstract}

Keywords: Austerities, 'He desired May I be many', Self-Creator, Space-Creator, Ultimate Reality-Brahman.

Submitted Date 19 June 2013

Accepted Date: 24 June 2013

\section{INTRODUCTION}

Beginning everything of cosmos including stars, planets, ethers, water, fire, air, soil, plants, beings, non beings and others; how! How all were evolved! In this world, what were the first products; trees or seeds, substance or universe, matter or life. Mountains, rivers, streams, planes, seas, oceans, animals in land and water surroundings, seen and unseen insects everywhere, how they are created? Where there was any creator or group of creators at the beginning? If it was, how was the beginning? Before beginning, who was the beginner? If there was a beginner, how he looked? Where ever he lived? Why can't we see him now? All animals have start and end. Man born, live and die, never born and appear alike. Man never gets the same body again. Men come to the external world with different bodies, minds and walk, see, talk, listen, respond and live in a society. When a man dies, the man becomes corpse, the same man doesn't see, listen, respond and talk, why? Because the corpse has no mind, sense or anything, what is that? How they are created, come to existence? What men are creators of men? If it is, who was the first man and woman; 'Adam and Eve' or any other named or entitled? Who was the creator of 'Adam and Eve?'

Man preys animals and eats. Animals prey animals and eat to remove hunger. Man also eats plants and processing of plants' products. Generally, those who grasp others, they are eaters and which grasped by the eaters are food. The inter relation between eater and food how crucial? Every living and sensible beings in this world have right to live, spread anywhere in land, water and ether then why one can preyed, tortured by others? What the creator or creators made any rule and said to the sensible beings that 'you go and live in the world, prey others and collect plants as your food.' Sensible beings may born again and again but never born the same sensible beings with same bodies or any consciences repeatedly. So, why the systems of preying and grasping are continuing in between the sensible beings? What are the causes behind these effects? Are these sources inspired to search the real nature focusing to the centre point of the Universe? Let's find these causes.

\section{HOW WAS THE BEGINNING?}

Beginning something out of nothing is an impossible task. If it is true that nothing comes out of nothing than how strange to possible the creation of material world and living beings? Before beginning something, the materials requirement is a first choice. What type of material collected and by whom the creation of the Universe started, these are the problems to beginning. In every steps of life we require new things to refresh our mind i.e. we are not always satisfied with same kind of things or facts repeatedly done, we need change. But this world changes by natural phenomenon. And also sometimes humans' population explosion makes artificial and bound to natural changes, cause of deforestation and vanishing of mines. So that nature breaks its law, become severe to change and balance.

But, that type of change is not a change, if we believe God has created nature. If God created nature and Universe, why He can't creates the world which is free of old-age, death, sufferings, pain, pleasure, day, night and others, where man without any obstacle, changes to immortal being, the world transferred unto a heaven, all man feel potency of God. Here I think we are creating God, a Devine power who regulates us and 
the Universe. It is an empty statement with fear of death and sufferings. That's why we are facing problems which counted as unconditional sufferings appeared to avoid the moment of joyful life.

All Gods were not deities but born as humans in this world from human mothers not deities' mothers within particular time and space, learned as pupils of different teachers, grow as all stages of life which faced humans, struggle to live on peace and harmony, face obstacles, strive to preach morality among all peoples, becoming instances of real humans and humanities which the society look forever. At the end, all sufferings make them examples of becoming perfect humans as Gods. Therefore all Gods are humans and Gods are created, believed, supported by humans. There will be no Gods, if not a men, there will be men, if not a particular God. Men are everywhere in this world, but Gods disappeared with death, we just believing their existence because we are humans, we have knowledge about themselves opening historical manuscripts' written by the humans not deities.

Another problem is to be identified and justified here, if man knows the humans are God gifted, after that in some situation he can't help others even a lonely, orphan child tortured by the believer of God. Is the devotee a person of love, believing truth, bliss and consciousness? Never, I think that person believes God either blindly or he knows God is not here to see his acts of cruelty and appearances done by him as an immoral action noticed by the society. Isn't it a problem of society to think, to behave, to make a healthy environment, where a single man never rests without home, eats which food all are eating, drinks water with purity. Is it genetic that some people live with limited food and zero shelters? No, it is neither genetic nor reduced from genes. The situation makes them becoming helpless. For this sense we are not exactly the believers of God, we believe because we have fear of death and sufferings. When we suffer we think about God, worship the image of God but not to God, this is also a problem because we are knowingly refusing the real nature of God.

\section{I. Big Bang Philosophy}

'It is a common misconception that the Big Bang was the origin of the universe. In reality, the Big Bang scenario is completely silent about how the universe came into existence in the first place. In fact, the closer we look to time "zero," the less certain we are about what actually happened, because our current description of physical laws do not yet apply to such extremes of nature. The Big Bang scenario simply assumes that space, time, and energy already existed. But it tells us nothing about where they came from or why the universe was born hot and dense to begin with.' [1]

$1^{\text {st }}$ hypothesis of Big Bang philosophy: 'The universe, finite and intelligible in all its parts, cannot be infinite and unintelligible in its whole. It cannot have two completely different natures simultaneously. The infinite is a philosophical concept of the absolute that does not apply to the universe. If the universe came into being around 12.000.000.000 years ago, it has not had the time to become infinite. Limited in time, it is also necessarily limited in space. If the universe were infinite, it would present particularities so strange as to be absurd. For example, a human being having a finite number of atoms, in an infinite universe every one of us would have an infinite number of doubles living in exactly the same conditions as ourselves.' [2]

\section{II. He desired to become many}

How beginning appeared? An important question arise in all rational being as human, to find the answer many ways, separate paths are discovered but the human can't reach at the solution of the particular question, because of huddles surrounded them. Science reached in the top level of observation and experiment to prove the root cause of the creation of solar orb but yet not completed successfully. Philosophy also made milestone for space science, where to enquire all the things happened by which ways. And how much space covered by the universe, where is the point of beginning? In this context Taittirīya Upanishad says; 'He desired: May I, be many, May I, be born. He performed austerities. Having performed austerities, He created all this, whatever there is. Having created all this, He entered into it. Having entered into it, He became both the manifested and the unmanifest, both the defined and undefined, both the supported and unsupported, intelligent and the non-intelligent, both the real and the unreal. The Satya-truth became all this: whatever there is. Therefore call it the True. Hence to become one to many, Brahman evolves.' [3]

Creation is interpreted in the Védas as a developmental course rather than as bringing into being something not hitherto existent. It was considered as an ongoing-process and not an event. He is conceived as a cosmic person with a thousand heads, eyes and feet, who filled the whole universe and extended beyond it. The world form is only a fragment of this divine reality. The first principle which is called Purusa manifested as the whole world by his tapas-austerity.

Now this is in a different way, the subject of the Taittiriya Upanishad also, wherein we are given a cosmological treatment of the entire bondage of the soul and the process of the liberation of the soul from this bondage. As the Aitaréya told us that the one Ätman alone was, nothing else external to the Attman existed, it became the many as the Universal and entered into it, and projected itself as the various divinities, became the jīva, had these experiences etc., so does the Taittirīya Upanishad also tells us. 
The original being is satyam, jñannam, anantam; or we may say satyam, jūannam and annandam that are called in short sat-chit-änanda, where there is a simultaneous experience of everything, not a successive experience of particulars as we have today. In that state of Brahman, there is an instantaneous experience of all things. Even when we use the word 'instantaneous', the idea of time lingers in our mind. We cannot get rid of the idea of the time factor. We think everything is experienced at the same time. This is how we think in our own temporal way. It is not a simultaneity of temporal events that is called an instantaneous experience there. It is a timeless experience, because it is space less being.

\section{III. Space is the first product}

Space-Creator, the term is different from Self-Creator. The term space means dik-direction, where the object perceived whether it is in what exact place we find that material thing. The object covers a place, that place defines directions as east, west, north and south vice versa. Hence, space is not created but demarcated to find the actual position of any object. But the word Space-Creator also refers to the Creator of sky-ākäśa. The concept of space here, the place acquired with normal direction which within a content. 'The first manifestation is space-ākäśa. Space is all pervasive and the subtlest; it has the quality sound.' [4] This theme gives a description of the evolution of the universe from fine to gross. It illustrates how the five great elements have emerged in a sequential order out of the Supreme, Brahman. Initially there is Brahman, Brahman everywhere. Brahman at this stage is nirguna, nirākāra - without qualities and without a form. We cannot say what it is like.

A question arises, if Brahman is the Self-Creator created space than what were before the creation of space-ākāśa? Was that only fire or air anything else. Nothing! That was vacuum, empty paradise, where we can't find any space because space is an identification of where all things move as like, no movement is possible except space. The total domain of Universe is not identified as space, cause; space is also within and outside of other particles and independently acts to form another. Space is not understood as Brahman but the Universe is Brahman. From Brahman evolves space, hence He is Space-Creator. The first element to evolve from Saguna Brahman is $\bar{a} k \bar{a} s a$, which is usually translated as space or sky and sometimes as ether. The creation or evolution of $\bar{a} k \bar{a} s \dot{a} a$ really means that Brahman, in association with Māyan, appears as $\bar{a} k \bar{a} s \dot{a} a$, further appears as air and other three particles.

Upanishad tells us that there is the city of Brahman, the Absolute, in our own Self. A very small lotuslike abode exists in our own heart, and in this little abode, there is a little space which shines by its own light. What is there in that space? To know this is our duty. It is our duty to understand what is inside this little space in our own heart, which is inside the city of Brahman, which is very small and looks like a lotus. This is the city of God. Some people may ask, what is inside this? What is this great secret you are speaking about?

'There is a space within the heart; in it lays the Person consisting of mind, immortal and luminous. The spinal cord nerve passes through the piece of flesh which hangs down like a nipple between the two palates and ends where the skull splits and the roots of hair lay apart. That spinal cord is the path for the realisation of Indra. The souls of the aspirants passing through the spinal cord, rests in fire, represented by the vyāhruti Bhüh; he rests in the air, represented by the vyähruti Bhuvah.'[5] This is one of the highly cryptic sections of the Upanishad and it is not easy to deduce its meaning directly. It is said that even the teachers could not give us a ready explanation of these mantras without supplementing them with their own words and ideas. With this setting let us try to understand this mantra-hymn as much as we can.

This mantra is about meditation on Saguna Brahman. In Védānta the heart is considered as the abode of the Lord. It is stated to contain within it space which is to be meditated upon as luminous and as a symbol of Brahman. Brahman is called Purusa because He dwells in the body. He is Consciousness and can be realised by purified minds alone. Sushumnā nerve which goes upward from the heart to the centre of the skull is considered the doorway to realisation. It is the path by which the aspirant attains the goal without coming back to the world of rebirth. Such an illumined soul, after coming out of the body, becomes established in fire represented by the vyāhruti Bhüh, which is as it were a limb of Brahman. Similarly he is established in the air which is another limb of Brahman represented by vyāhruti Bhuvah.

'You ask me what is inside this little space. I tell you that everything is inside here,' says the teacher in Taittiriya Upanishad. It is like a speck of sunlight. Though it may look like a speck, it contains constitutionally everything that is in the orb of the sun. Similarly, that which is in this little space can magnify itself to any extent. It is an emblem of the cosmic secret. Whatever is the extent of this vast space that is outside, that is the extent of this little space in our own heart also. So, one should not be under the impression that it is little in an arithmetical sense. It is little in a different sense altogether. It is not physically small. It is not a little handful of space. It is really as expansive and as extensive as this universal ether that we see outside. The whole of the heaven and the whole earth can be found inside this little space. The principles of the five elements as earth, water, fire, air and ether and whatever you see outside, is all present here in this little ether. The sun and the moon and also the stars can be seen inside this very heart of ours. They have a corresponding emissary planted in our own heart. We need not look up to the sun outside. He is inside our heart and he shines in the same way 
as he is seen outside in outer space. Even the lightning and the thunder that are seen outside are taking place inside our heart. Everything that happens in any manner, even the littlest thing, takes place here inside. Whatever we see in the outside world and whatever we cannot see in the outside world, all those things are inside our heart. Well, the heart inside seems to be a greater mystery than the outer world. Whatever we cannot see in the whole world also is here, says the Upanishad.

Why is it that we cannot see everything in the outer world, and why should everything being inside our own heart? Because, our heart which we call; the self-hood of our being is the true representative of the Ultimate Reality. The outer world cannot be regarded as such a representative. The externality that is characteristic of the outer world prevents it from revealing everything that is in the Supreme Being, whereas one of the aspects of the Supreme Being, which is subjectivity, is present in us. Externality is not a characteristic of God. Ultimately, He is subjectivity, and that aspect is present in us, although the outer aspects are not. Hence, while the incapacity of probing into the subjectivity of the external universe prevents us from knowing everything in the universe, there is a possibility of diving into our own Self and knowing all things at one stroke. As a matter of fact, all investigation in the field spiritual is internal and not external, because when a thing is externalized it is divested of the divine content. It thereby gets partially abstracted. What we call the outer world is only that aspect of Reality which can be comprehended by the senses. Whatever the senses are incapable of grasping cannot be contained in the external world. Only a little bit of the total value of the ultimate truth can be taken out by the vessels of the senses, more than that they cannot contain. What is sensed by the senses in the form of sensation is not the whole reality. They can take up only what they can contain and what they are able to cognize. It is one of the five elemental features of the external manifestation that the senses can present to us in experience. Hence, Brahman is the Space-Creator.

Now the Taittiriya cosmological treatment is as follows. The universe of the five elements ether, air, fire, water, Earth is a condensation, as it were, of the Atman itself. There was a gradual descent of the Atman into greater and greater particularity, and together with it greater and greater externality. There is particularity, externality and gross of the cause into the effect. As described earlier in this chapter, from that Brahman indeed, which is the self was produced space-äkāśa. Here we reduced according to Taittirīya Upanishad; 'from the space emerged air, from air was born fire, from fire was created water, and from water sprang up earth. From earth were born the herbs and from the herbs was produced food. From food was born man and that man such as he is surely a product of food.' $[6]$

The individual being comes as a consequence of these universal manifestations of the elements. Here again, even in the Taittiriya, we stand as effects to the Universal which stands in the position of a cause, as in the case of the doctrine of the Aitaréya. Though the universe is an effect of God, it is a cause of our experience. We have no control over the elements. We cannot order the earth, water, fire, air or ether to behave in this way or that way. In this sense, they are causes of our experiences. The objects precede our experience. There seems to be some great point in the doctrines of realism as well as idealism, which are the dominant schools of philosophy. The realist holds that objects come first, experience comes afterwards. But the idealist thinks that experience comes first and the object afterwards.

There is a great quarrel among these schools of thought, but there need not be any quarrel. Both these standpoints seem to be correct because they speak from different positions and different points of view altogether. There is a metaphysical idealism implied behind even the empirical realism of perception of objects. We perceive the world, no doubt, as something external to us, and we know very well that the world was there even before we were born; therefore, realism is right. The world of objects in its physical form precedes the experience thereof by the individual experience. But idealism is also right, because there is a consciousness underlying the very manifestation of the things. The whole universe ultimately can be reduced into consciousness, because the objects which are apparently external to us are conditioned by this perceiving consciousness in various degrees.

The Taittiriya tells us that there was thus the creation down to the earth and from the earth evolves vegetation of various kinds, herbs or aushadhis which became the diet of the individual - the Purusa, 'aushadhibhyah annam, annāt purusah'.[7] The individual grows out of the food that he takes. Here is again an interesting factor that we have to observe. We are constituted of Annam or food. It is not merely the physical body that is constituted of food; everything that we are is nothing but the food that we take. As cloth is made of threads, or as any composite object is made up of the component factors, so is the total individuality of ours, including the psychic individuality, constituted of certain bits of experience and bits of matter.

Thought is nothing but the various functions it performs. The various feelings and emotions and the volitions put together constitute what we call the mind, the fabric of psychic personality. The body again is constituted of these elements only earth, water, fire, air and ether, etc. Everything in the so-called individuality of ours is a composite structure of various factors which can be dismembered and broken into their component parts. These compositions of individuality become the causes of the various experiences we pass through in our life. Our experiences are through the layers of our personality. These layers are called sheaths-kośas in the 
language of the Upanishads. A kośa is a sheath, like a sheath or scabbard for a sword. These sheaths are something like peels of onion growing one over the other, and while there can be many such layers conceivable, five of them are mentioned as predominantly experienced by us in our day-to-day life. These are the so-called annamaya, prānamaya, manomaya and vijñānamaya and ānandamaya kośas.

These kośas are not actually like peels of an onion, though the illustration gives some idea of what these kośas are, because one peel of an onion is not connected with another peel. They are independent; but the kośas are not so independent. They are various gradations of density, one slowly passing into the other, and we cannot know where one begins and where one ends. Thus, we can finally say that there is only one kośa, which appears as fivefold on account of the gradations of density, all of which are ruled over by the central light of the Atman. All this is, of course, out of our sight. We have descended so low into the physical externality of our experience that the Atman, which is universal in its original status, has project edit self out of the senses and come out of the body, as it were; it is now looking back towards its own self as an object outside. It has completely lost itself in matter. To lose itself in matter is not so bad as to come out of it and then look upon it as an object of its own self. This is what the senses do. So in one sense we are far, far removed from reality, much more than even inorganic matter, because we have come out of the material body and then projected our consciousness backwards, as it were, looking to matter as an object of our own self.

The universal consciousness has been completely buried in the material content; and after getting buried, it comes out of it in a reflected form, becomes the jī $v a$, and looks at its own body as an external something. So we can imagine why there is desire for objects. It is the desire of the Atman for its own self. It is not asking for anybody else; it wants its own self. The whole world is such a crazy house of delirious individuals. What has actually happened to us we cannot explain, and the less we say about it the better? Such a catastrophic event has taken place, which we regard as heaven itself. How happy we are in the world! We are very happy with a cool drink, with a fan or a refrigerator.

Everything gives happiness to us, but we do not know that we are diseased to the core and we are trying to scratch the itch to some extent to see that it does not give us agony in an intensified manner. We are not going to cure the disease. No activity of ours in this world can be a cure of this disease of samsära, from the point of view of the magnitude of the suffering in which we are involved and the magnitude of the catastrophe that has taken place. It requires a herculean task to bring the consciousness back. Mere activity born of ignorance is not going to be an aid.

We have heard people say that Acharya Shankara was against karma. There is a point in what he says, though many people do not understand what the implication of his statement is. Every action that we do normally is a movement of ignorance in the direction of an object that is there outside apparently, but not really. How can a movement in the direction of an apparently existent something liberate us from bondage? If our activities are directed to the sublimation of individuality, and have as their purpose the universalisation of our status, that could be Karma-Yoga. That is not what Acharya Shankara condemns. He condemns karma which is binding in its nature, which is born of the ignorant feeling that body is real and, therefore, everything that is associated with the body is also real. An activity that is directed to self-satisfaction of the body is bondage. That is not going to liberate us.

But all that we do in this world is nothing but that. We are not doing Karma Yoga. We should not be misguided. If we are consciously directing our activity towards the efflorescence of our individuality towards the Universal, then it is Karma Yoga. On the other hand, if we merely drift like a fly from place to place, it is not Karma Yoga. Any activity involving sweating and toiling cannot be called Karma Yoga unless the consciousness is there behind it. Otherwise, it becomes an ordinary, empty, humdrum activity which is impulsedriven rather than consciousness-motivated. This distinction has to be carefully drawn. Impulse driven activity is different from consciously directed yoga practice.

And how many of us are conscious of what we are doing? We are driven by impulse only. When we are feeling hot because of the atmosphere outside, we feel like mitigating it by a contrary activity. When we are hungry, we are doing something contrary to it. Everything that we do is a contrary activity in respect of the particular experience through which we are passing. We have no idea of the basic disease behind it or the ideal that is ahead of us. But if this is clear, well, it cannot be called action. It is a movement of consciousness. So these are the five koshas. The annamaya kośa is the physical body. But it is not that the physical body comes first in the process of creation; the causal body comes first. The causal hardens itself into the subtle, and the subtle becomes the gross. These three bodies are the objects of experience in the sleep, dream and waking conditions, respectively. It is the causal body that we experience in sleep, the subtle body in dream, and the physical body in waking. These three bodies are subdivided into the five kośas, or the sheaths. The innermost one is called the annandamaya kośa. The next one is called the vijñannamaya kośa. Further to it is the manomaya kośa. Then we have the prānamaya kośa, and lastly we have the grossest one, the annamaya kośa.

The annamaya kośa means the physical sheath constituted of the food those we intake. Anna is food; and the various impressions created by our sensory experiences contribute to the stability of the body, including 
the physical food that we take. And here we have a marked distinction of the limbs of the body as head, ear, nose, etc. We can feel that the various limbs of our body are completely cut off from the limbs of the bodies of others. In spite of the Upanishad crying out that all this manifestation has come from the One, we are least conscious of this fact, and we cannot even dream at any time in our life that we have any connection with the wall standing out there. Such is the condition of physical experience, where limbs are cut off completely into a little prison house of this body in which the Atman abides, as if it is its own property.

Now these activities of the physical body are driven or motivated by inner impulses coming from higher realms, and these subtler realms which are more pervasive in their nature are the other kośas mentioned, which are inside the physical body. We are not the physical body only, as many people may mistake themselves to be. Inside the physical body there is an energy body; it is called the prānamaya śarìra. The subtle electric force that energises the whole physical system, as copper wires are energised by or charged with electric force driven by the power house is the prāna. The prāna is an invisible śakti; it is a power. We cannot define it, just as we cannot define electricity. It is what we call the life principle, the breathing process; and the sense of 'life' that we feel in us is due to the presence of the activity of the prāna.

It is difficult to translate this word into English. It is vital force, vital energy, life principle, or whatever we may call it. Just as in a live wire electric energy charges every particle or atom of the wire and we cannot know which is the wire and which is electricity but if we touch the wire we will get a shock, likewise we cannot know which the body is and which the prāna is. They have become one, so that if we touch any part of the body, it looks as if we are being touched. Our life has become one with the vehicle which is the body; the vehicle has become one with the driver. They are identical; we cannot separate one from the other. Now, this prāna is the external-most manifestation of a still subtler energy which we call mind. The mind is transparent enough to reflect the consciousness of the Atman, whereas the prāna is not so transparent. It is opaque, comparatively; it is rajas-ridden, and it is very active. Wherever there is an excess of activity or rajas, there cannot be a reflection of the Ätman and therefore, prāna does not reflect consciousness.

It requires the help or aid of the mind that is more transparent in its nature. Though the mind too has rajas and tamas in it in a certain percentage, it has a greater predominance of sattva in it. So the thinking faculty or the psychic faculty becomes the interior controlling agent of the other external sheaths, the pränamaya śarīra and the annamaya śarira. The sense organs are contained in this body. We are generally told that the karméndriyas or the organs of action speaking, grasping, locomotion, etc., which are the tendencies to action and the limbs that help such activity are all motivated and controlled by the prāna.

The prāna is the synthesised form of räjasik force, and the karméndriyas, or the organs of action, are the discrete or the diversified forms of the same energy. So we may say that all our activities are nothing but prāna working. But these activities have ideas behind them, thoughts behind them. Thoughts precede action. The mind together with the senses of knowledge constitutes the manomaya kośa, or the mental sheath. Here we are in an animal level practically. On the panic level, we are like vegetables and on the purely physical level we are like inanimate matter. But on the thinking level, we are like animals, and only on the intellectual level are we superior to animals. That is a still higher stage. The vijñana, or the intellect, is something like a purified form of the mind. It is purified in the sense that it is capable of determinate thinking, while the mind is usually engaged in indeterminate thinking.

There is a translucent feeling of the presence of things and an indistinct thought of objects outside when the mind operates. It cannot decide, it cannot judge, it cannot discriminate, it cannot argue, and it cannot come to a conclusion. This is the mind, as we see it operating in animals, for instance. This is what we call the instinct level, when we are not self-conscious to the extent necessary for judging things in terms of pros and cons, etc. The senses of knowledge seeing, hearing, etc. are the manifestations of the mind, just as the organs of action are the manifestations of the prāna. While the organs of action are in the prānamaya kośa, or the energy body, the senses of knowledge are in the manomaya kośa, or the mental sheath. They are internal because they are conscious in some way, whereas the prāna is not conscious; it is simply active. The manomaya kośa, or the mental sheath, acts in collaboration with the vijñannamaya kośa, or the intellectual sheath, which also works with the aid of the senses of knowledge, so that we may say the intellect, the mind and the senses of knowledge form a single family. They are a single group, and they work together. This is the highest point of individuality conceivable. We are now on the intellectual level, having risen above the mental level, the prāna level of the vegetable kingdom, and the inorganic level. So, we are able to think in a logical fashion, understand the causes of effects, and effects of causes, etc., and link causes with effects.

This is a prerogative of the human individual that causative thinking is possible, whereas animals are incapable of doing that. They cannot remember things as we do. We can think of the past, and we can think ahead. This is the intellectual level. Now, consciousness brilliantly manifests itself in the intellect, no doubt; but we are not satisfied merely with the intellect. Understanding alone does not make us happy. Happiness is a different thing altogether. The great Reality, the Supreme Being, is said to be constituted of three constitutive essences, we may say: sat, cit and änanda Existence, Consciousness and Bliss. We can see existence even in a 
wall or a brick, but not consciousness. We can see existence and consciousness in a human being where the intellect functions when we think, or argue and speak; but we need not be happy at that time. So happiness is not necessarily a condition which follows intellectual functions because even in the intellect there is an element of rajas. Happiness is possible of experience only when there is freedom from rajas totally. There should not be rajas or tamas if we are to be happy. If there is tamas, we will be asleep like a stone. If there are rajas, we are awakened from sleep and we are conscious of things, but not happy. In that condition of rajas, we are like muddled water which is shaky, where a reflection of the sun is possible, but not a clear reflection. Only when sattva predominates is there a clear reflection of Reality and we can experience happiness. Happiness is what we seek. We can understand that it is not ordinary knowledge that we are after in this world. We are after knowledge for the sake of a satisfaction that it brings. And, how knowledge brings satisfaction is a very important topic. Happiness is what we are after; it is happiness for which everyone works, and happiness seems to be the aim and objective behind even the operation of consciousness in this world. Consciousness is incomplete, and existence is incomplete, if bliss is not there. That bliss is the ultimate content of the Absolute.

Hence, Ultimate Reality - Brahman made beginning of this world and other worlds also to be many and find His broadest, unlimited and unthinkable outweigh measure of joys. So that, it is only to judge what is continuing in our surroundings. A thought of evolution is how systematic that followed from this world that when sky emerged then air, fire, water and earth formed, the sun becomes incomplete; because, there is sky, air and fire contains inside and outside the orb, but there is no water there. It helps to create water in the world and other planets. It's imaging, uniformed in nature. Therefore the creation is how and when started is not so important here, but to meditate upon the universe, where all are becoming food to each other. Here, sun with its solar family how grasping the sky and the sky also eating all stars, planets, even to the earth, moon and others. We are also as food grasping always by the space itself and eating different food to live.

\section{IV. The Ultimate Reality is Self-made}

Self-Creator is a term which means the creation is made or created by the same creation, the creator created Himself by Him. He is the Self-Creator who created own self by the process of creating something to give existence. It is clear to all that a self-creator means the creator pre-existed before his creation. His creation is nothing started in a moment we are trying to prove it. It is just an impossible task for human being or any other talented being of universe to demarcate the unlimited existence of the Creator, because the Creator himself is infinite. There-fore, Self-Creator means the Creator who is not created but existed earlier before creation.

He has not come but present. It is possible to have a doubt whether Brahman exists or does not exist. To clear this doubt the Upanishad goes in great details regarding the origin of creation and evolution. 'In the beginning all this was non-existent. From it was born what exists. That created itself by itself; therefore it is called the self-made. That which is Self-made is flavor; for truly, on obtaining the flavor one becomes blissful. Who could direct the prāna and the apāna if this Bliss did not exist in the ākāśa? Brahman verily exists because it alone bestows bliss.' [8]

'Before manifesting this universe of sentient and insentient was non-existent i.e. was in an unmanifest state. From that came the existent with names and forms. Brahman transformed Him by Himself into the universe of sentient and insentient objects. Therefore, He is known as sukruta - the self-created.' [9] All beings make movements and act only with the support of Brahman, the bliss itself. All physical actions in the world are made possible only because of Brahman. Therefore, the seeker must believe that the Lord does exist and provides joy to everybody. In Brahman, till then there will be fear of birth and death. This fear will be experienced by not only the ignorant but the wise also if they are proud to know that existence.

Aitaréya Upanishad says, "in the beginning all this verily was Atman, the Absolute Self only, one and without a second. There was nothing else that winked. He, Atman willed Himself: 'Let Me now creates the worlds'." [10] It is reduced here the absolute self only was present without another existing entity in Universe to make and feel something different. That was happened, He - the Lord creates everything. And enter in His creation to make conscious and different. So it is also understood here, Brahman makes worlds before that $\mathrm{He}$ was present. He, Himself the Universe, the Maker, the only Founder and becomes many. So He is the SelfCreator.

\section{CONCLUSION}

It's not one of the final judgments to know the evolution of the earth and universe, to prove 'how was the beginning'; rather it is a critical analysis to make a destination for different search on this context. Humans are the top most evolution of the Ultimate-Reality, to feel the potential base and the domain of truth, consciousness and bliss. Here, it is reduced that the Big-Bang may be a true concept of evolution of solar orb and galaxies but not the cause of the Universe. Because, when the Big-Bang happened the Universe existed. In the Universe the Big-Bang started.

It is possible that a beginning of creation or evolution of earth and others, which are seen and unseen particles but not that where these are existing as the universe we called. The Ultimate Reality is refers to the 
universe we are part of that infinite, unbelievable all and one without second, a supra-limiting conscience, no definitions are established for Him.

It is also possible that we can't imagine because, we have no such limitless area where we go and find the causes even know the food digestive systems without the help of technology. We just see how our digestive and respiratory system are functioned but never make all systems and blood because, we are not able to make that, only review, help to make secured for the time being by medicine or surgery. Thus, the beginning of this creation is possible.

\section{References}

[1] David L. Alles, 'The Evolution of the Universe' (Western Washington University, 2012-10-8)

[2] Jean-Pierre Burri, http://www.bigbang.org/ jpburri (Geneva, Switzerland, Last updating: 16 August 2001)

[3] Swami Gambhirananda, Eight Upanishads, Volume One, T.U. (Advaita Ashram, Calcutta, 1991) Part-2, Cha-6.I

[4] Swami Gambhirananda, Eight Upanishads, Volume One, T.U. (Advaita Ashram, Calcutta, 1991) Part-2, Cha-1.I

[5] Swami Gambhirananda, Eight Upanishads, Volume One, T.U. (Advaita Ashram, Calcutta, 1991) Part-1, Cha.-6.I

[6] Swami Gambhirananda, Eight Upanishads, Volume One, T.U. (Advaita Ashram, Calcutta, 1991) Part-2, Cha-1.I

[7] Swami Gambhirananda, Eight Upanishads, Volume One, T.U. (Advaita Ashram, Calcutta, 1991) Part-2, Cha-1.I

[8] Swami Gambhirananda, Eight Upanishads, Volume One, T.U. (Advaita Ashram, Calcutta, 1991) Part-2, Cha.-7.I

[9] Swami Gambhirananda, Eight Upanishads, Volume One, T.U. (Advaita Ashram, Calcutta, 1991) Part-2, Cha.-7.I

[10] T. N. Sethumadhavan, Aitaréya Upanishad, (Esamskriti.com, 2011, Nagpur) Part-1.1.I 